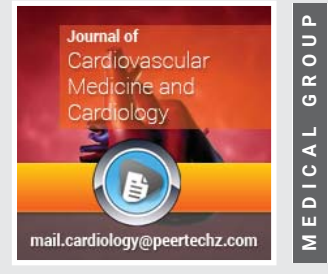

Short Communication

\section{Recognizing the fundamental flaw in our dietary studies investigating the impact diets, drugs and lifestyle have on preventing or reversing CAD}

\author{
Richard M Fleming', Matthew R Fleming ${ }^{1 *}$ and Tapan K \\ Chaudhuri $^{2}$
}

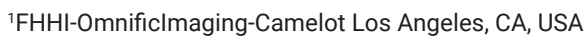

2Eastern Virginia Medical School Norfolk, VA, USA
Received: 23 December, 2019

Accepted: 20 February, 2020

Published: 21 February, 2020

*Corresponding author: Richard M Fleming, PhD, MD, JD, Los Angeles, CA, USA, E-mail:rmfmd7@yahoo.com

Keywords: FMTVDM; Inflammation and heart disease theory; Angina theory; Primary prevention CAD; Secondary CAD treatment; Food fight; Heart disease; Cancer; LowCarb; KETO; Vegan; Ornish; Statins; PCSK9-Inhibitors

ORCiD: https://orcid.org/0000-0001-9964-1518

https://www.peertechz.com

Check for updates
Since the introduction of the (a) Inflammation and Heart Disease, and (b) Angina, Theories in the mid-1990s, a transition from a cholesterol only etiology for coronary artery disease (CAD) has taken place; resulting in an understanding that $\mathrm{CAD}$ is the result of an Inflammatory process precipitated by a number of factors-including, but not limited to LDL cholesterol and saturated fat [1-5], which impair coronary blood flow.

Unfortunately, hundreds if not thousands of research studies-involving millions of dollars in vested funding - have focused on measuring changes in weight and blood tests $[6,7]$ rather than measuring actual changes in CAD itself [8-10]. Even the few dietary studies, which actually measured changes in CAD [11-14], provided only semi-quantified results - based upon the limited quantification methods available at the time of the studies [10].

The consequence has been a fusion of misinformation, fueled by opposing factions of scientists and pseudo-scientists resembling more of a schoolyard brawl than an actual scientific search for the truth. From this, physicians, the media, and social scientific neophytes have vied for attention in support of their positions - demonstrating more social consternation than scientific discourse.
Consequently, fundamental questions regarding the impact of diet, drug, and lifestyle treatment effects on CAD [15-18] remain poorly addressed, due to the lack of actual measured effect these diets, drugs and lifestyle have on CAD itself [810]. Confusion about what constitutes true quantification has further confounded investigations of the impact of diet and drug treatments for both primary and secondary prevention and treatment of CAD $[10,19]$. Thus the role diet, drugs and lifestyle play in preventing and treating CAD remains nothing more than a social media fight [20-23].

The first step to solving any problem is recognizing there is one. To date, studies looking at the primary or secondary prevention of CAD using dietary, drug, or lifestyle intervention, have been severely limited by the absence of quantified measurements of the changes in $\mathrm{CAD}$ following treatment intervention $[9,10]$. Measurements of blood tests and weight do NOT and have NOT answered this question-resulting in a need for new studies to be done to address these deficiencies and answer the fundamental question of what impact various diets, drugs and lifestyle interventions truly have on CAD $[16,18]$ (Figures 1,2).

\section{Acknowledgments}

FMTVDM issued to first author. Inflammation and Heart 


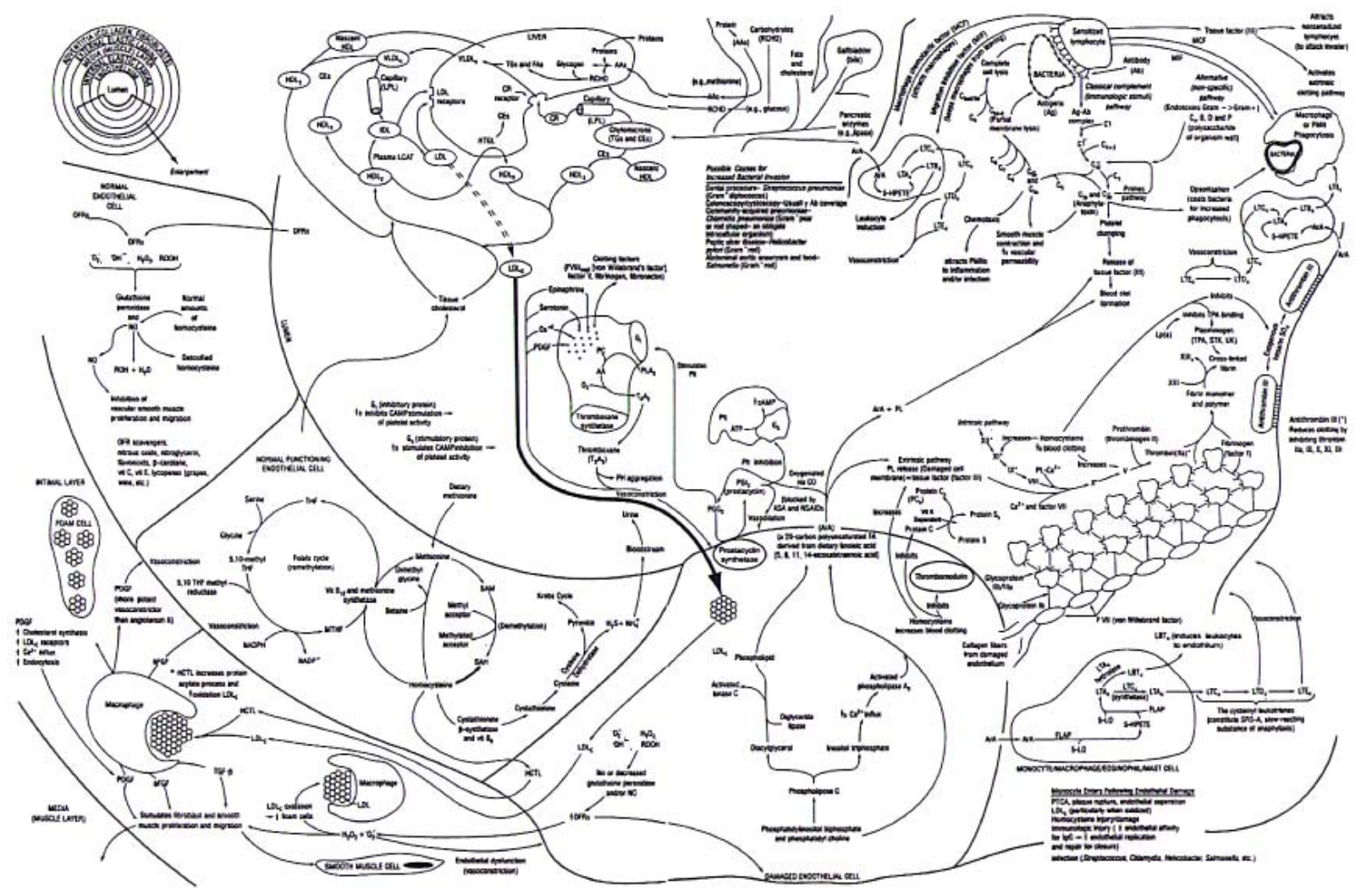

Figure 1: Coronary artery disease is an inflammatory process precipitated by more than a dozen variables. Each variable contributes to inflammation within the blood vessels of the body, including the coronary arteries to varying degrees in different individuals [1]

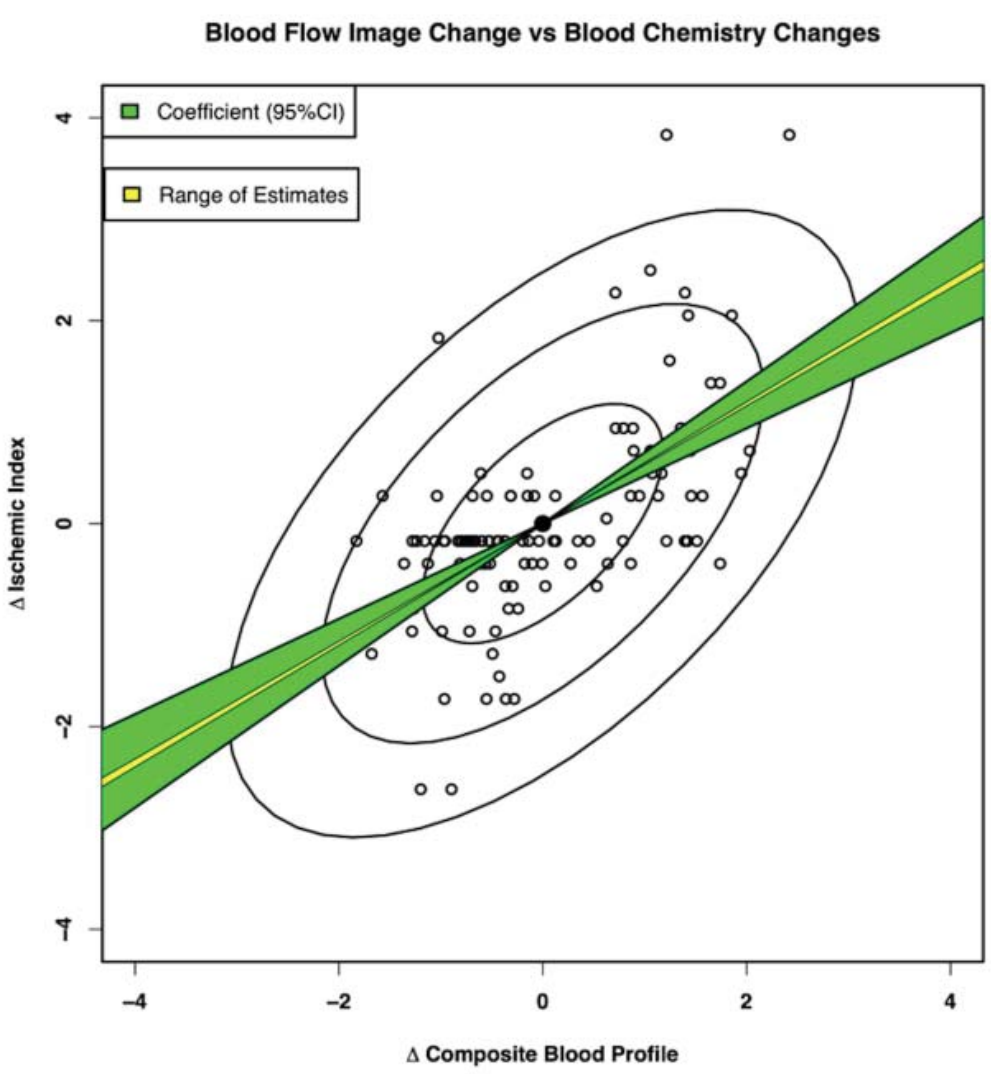

Figure 2: The X-axis displays the composite blood profile including TC, fat, low HDL, IL-6, Lp, and Fib. The Y-axis displays changes in ischemia as measured by semiquantitative nuclear imaging. The standard regression analysis shows both the range of estimates (yellow) and the $95 \%$ confidence intervals (green). HDL, high-density lipoprotein; IL-6, interleukin-6; Lp-a, lipoprotein-a; Fib, fibrinogen; Tc, total cholesterol [8]

Citation: Fleming RM, Fleming MR, Chaudhuri TK (2020) Recognizing the fundamental flaw in our dietary studies investigating the impact diets, drugs and lifestyle have on preventing or reversing CAD. J Cardiovasc Med Cardiol 7(1): 036-038. DOI: https://dx.doi.org/10.17352/2455-2976.000109 
Disease and Angina Theories authored by first author. Figures expressly reproduced with permission of first author.

\section{References}

1. Fleming RM (1999) Chapter 64. The Pathogenesis of Vascular Disease Textbook of Angiology 787-798. Link: http://bit.ly/2tU8JN5

2. Fleming RM (2003) Stop Inflammation Now! with Tom Monte. Published by Putnam Books and Avery Books. ISBN: 0399151117.

3. (2004) ABC 20/20 Segment on Inflammation and Heart Disease. Link: http://bit.ly/37FyjDI

4. Fleming RM, Boyd L, Forster M (2000) Angina is Caused by Regional Blood Flow DifferencesProof of a Physiologic (Not Anatomic) Narrowing, Joint Session of the European Society of Cardiology and the American College of Cardiology, Annual American College of Cardiology Scientific Sessions, Anaheim, California, USA, 12 March 2000, 49th (Placed on internet www. prous.com for physician training and CME credit, April 2000.)

5. Fleming RM (2003) Angina and coronary Ischemia are the result of coronary regional Blood Flow Differences. J Amer Coll Angiol 1: 127-142.

6. Shah B, Newman JD, Woolf K (2018) Anti-Inflammatory Effects of a Vegan Diet Versus the American Heart Association-Recommended Diet in Coronary Artery Disease Trial. J Am Heart Assoc 7: e011367. Link: http://bit.ly/2HFL5Hu

7. Tertsunen HM, Hantunen S, Tuomainen TP, Virtanen JK (2020) Healthy Nordic diet and risk of disease death among men: the Kuopio Ischaemic Heart Disease Risk Factor Study. Eur J Nutr. Link: http://bit.ly/3bWvDVA

8. Fleming RM, Harrington GM (2008) What is the Relationship between Myocardial Perfusion Imaging and Coronary Artery Disease Risk Factors and Markers of Inflammation? Angiology 59: 16-25. Link: http://bit.ly/2uR1wy8

9. (2017) The Fleming Method for Tissue and Vascular Differentiation and Metabolism (FMTVDM) using same state single or sequential quantification comparisons. Patent Number 9566037. Link: http://bit.ly/2GsXbTT

10. Fleming RM, Fleming MR, Dooley WC, Chaudhuri TK (2020) Invited Editorial. The Importance of Differentiating Between Qualitative, Semi-Quantitative and Quantitative Imaging - Close Only Counts in Horseshoes. Eur J Nucl Med Mol Imaging. Link: http://bit.ly/36tGke3

11. Ornish D, Brown SE, Billings JH (1990) Can lifestyle changes reverse coronary heart disease? The Lifestyle Heart Trial. Lancet 336: 129-133. Link: http://bit.ly/3bUa3kg
12. Fleming RM, Boyd LB (2000) The Effect of High-Protein Diets on Coronary Blood Flow. Angiology 51: 817-826. Link: http://bit.ly/2SYH6v5

13. Fleming RM (2002) The Effect of High-, Moderate-, and Low-Fat Diets on Weight Loss and Cardiovascular Disease Risk Factors. Prev Cardiol 5: 110118. Link: http://bit.ly/38H8GDK

14. Fleming RM, Fleming MR, Chaudhuri TK, Harrington GM (2019) Cardiovascular Outcomes of Diet Counseling. Edel J Biomed Res Rev 1: 21-30. Link: http://bit.ly/2V3Bp1v

15. Fleming RM, Fleming MR, McKusick A, Chaudhuri TK (2019) The Diet Wars Challenge Study: Insulin Resistance, Cholesterol and Inflammation. ACTA Scientific Pharm Sci 133-144. Link: http://bit.ly/2SG4KNU

16. Fleming RM, Fleming MR, McKusick A, Ayoob KT, Chaudhuri TK (2019) A Cal for the Definitive Diet Study to End the Diet Debate Once and for All. Gen Med 7: 001-009. Link: http://bit.ly/3bRtvhv

17. Fleming RM, Fleming MR, Chaudhuri TK, Harrington GM (2019) Cardiovascular Outcomes of Diet Counseling. Edel J Biomed Res Rev 1: 20-29.

18. Fleming RM, Fleming MR, Chaudhuri TK (2019) How Beneficial are Statins and PCSK9-Inhibitors? Scho J Food \& Nutr 2: 213-218.

19. Fleming RM, Fleming MR, Chaudhuri TK, McKusick A, Dooley WC (2019) Nuclear Imaging: Physician Confusion Over True Quantification and Isotope Redistribution. J Clin Cases Rep 3: 32-42. Link: http://bit.ly/3bVlyl6

20. Johnston BC, Zeraatkar D, Han MA (2019) Unprocessed Red Meat and Processed Meat Consumption: Dietary Guideline Recommendations From the Nutritional Recommendations (NutriRECS) Consortium. Ann Intern Med. Link: http://bit.ly/2SSLQIC

21. Rubin R (2020) Backlash Over Meat Dietary Recommendations Raises Questions About Corporate Ties to Nutrition Scientists. JAMA 323: 401-404. Link: http://bit.ly/2VdkuK5

22. Zhong VW, Van Horn L, Greenland P (2019) Associations of Processed Meat, Unprocessed Red Meat, Poultry, or Fish Intake With Incident Cardiovascular Disease and All-Cause Mortality. JAMA Intern Med. Link: http://bit.ly/3bP58kG

23. Dyer 0 (2020) Food fight: controversy over red meat guidelines rumbles on 368. Link: http://bit.ly/32921zu

\section{Discover a bigger Impact and Visibility of your article publication with} Peertechz Publications

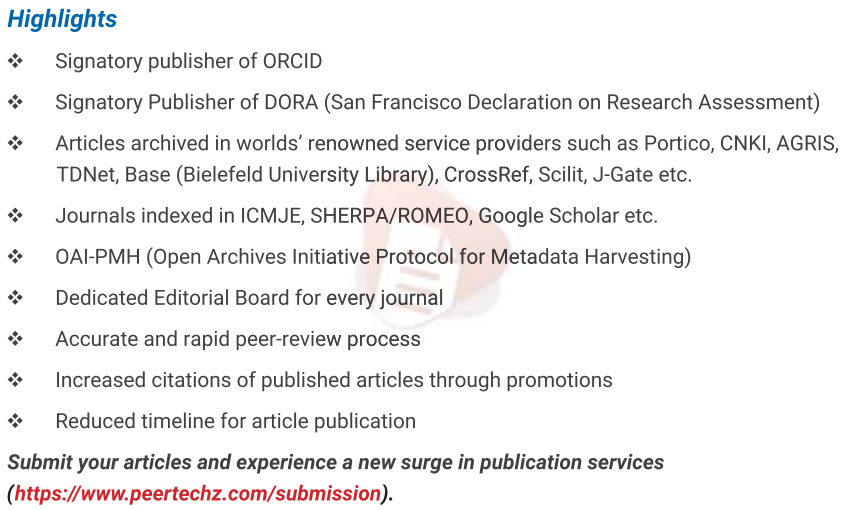

Peertechz journals wishes everlasting success in your every endeavours.

Copyright: @ 2020 Fleming RM, et al. This is an open-access article distributed under the terms of the Creative Commons Attribution License, which permits unrestricted use, distribution, and reproduction in any medium, provided the original author and source are credited. 